\title{
Population Status and Threats against Lyciasalamandra flavimembris (Marmaris Lycian Salamander)
}

\author{
Eyup BAŞKALE 1*, Doğan SÖZBİLEN ${ }^{2}$, Yağmur ÖZYILMAZ ${ }^{1}$, Ömer DİLBE ${ }^{1}$ \\ ${ }^{1}$ Pamukkale Üniversitesi, Fen Edebiyat Fakültesi, Biyoloji Bölümü, Denizli, Türkiye \\ 2 Pamukkale Üniversitesi, Acıpayam Meslek Yüksekokulu, Veterinerlik Bölümü, Denizli, Türkiye \\ ORCID ID: Eyüp BAŞKALE: https:/ / orcid.org/0000-0003-4489-8687; Doğan SÖZBiLEN: https://orcid.org/0000-0002-2267-1636; Yağmur \\ ÖZYILMAZ: https:// orcid.org/0000-0003-1614-1441; Ömer DILBE: https:// orcid.org/0000-0001-9189-5978
}

\begin{abstract}
Received: 09.05 .2019
Accepted: 14.06 .2019

Published online: 30.06 .2019

Issue published: 30.06 .2019

Abstract: We conducted field studies to monitor the population status of Marmaris Salamander (Lyciasalamandra flavimembris) in their known and possible distribution localities in Muğla province. The population status of and threats against the species were investigated and coordinates, elevations, and micro-climatic characteristics were recorded. We found out that the species is represented by at least 13 populations in the province of Muğla. Individuals prefer the areas that are more north-facing, with less sunlight and moist, and covered with vegetation where they can hide on the ground. The elevation ranged from 0 to 890 $\mathrm{m}$ and the mean temperature range was 8 to $18^{\circ} \mathrm{C}$ during the peak of the active period. Population density is calculated as 5.6 individuals/hectare. In addition, we re-estimated the extent of occurrence and area of occupancy of Marmaris Salamanders that are $1115 \mathrm{~km}^{2}$ and $79 \mathrm{~km}^{2}$ respectively.
\end{abstract}

Keywords: distribution, population density, active period, climatic condition, conservation

\section{Lyciasalamandra flavimembris (Marmaris Semenderi)'in Popülasyon Durumu ve Türe Yönelik Tehditler}

Öz: Marmaris semenderinin (Lyciasalamandra flavimembris) Muğla ilinde yayılış gösterdiği bilinen ve yayılış gösterebileceği lokalitelerde türün üreme dönemleri boyunca izleme çalışması gerçekleştirilmiştir. Bu kapsamda, türün bölgedeki popülasyon durumu, türe yönelik tehditler araştırılmış ve türün tespit edildiği yaşam alanlarının koordinat, yükselti ve mevkii bilgileri ile mikro iklimsel özellikleri kaydedilmiştir. Türün Muğla ilinde en az 13 popülasyon ile temsil edildiği, bireylerin yaşam alanı olarak daha çok kuzeye bakan, az güneş alan, nemli, bol bitki örtülü, zeminde saklanabilecekleri yarıklar olan yerleri tercih ettiği, bu bölgelerin deniz seviyesinden 890 m yüksekliğe kadar dağılış gösterdiği, en fazla bireyin saptandığı en aktif dönemlerindeki hava sıcaklığının ise $8-18^{\circ} \mathrm{C}$ arasında olduğu saptanmıştır. Popülasyon yoğunluğu ise 5.6 birey/hektar olarak hesaplanmıştır. Ayrıca, Marmaris semenderinin dağılış alanının $1115 \mathrm{~km}^{2}$ ve yaşam alanının ise $79 \mathrm{~km}^{2}$ olduğu belirlenmiş̧ir.

Anahtar kelimeler: populasyon yoğunluğu, aktif periyot, iklimsel şartlar, koruma

\section{Giriş}

Likya semenderleri grubu ilk olarak 1891 yılında Steindachner tarafından Muğla'nın Dodurga köyü civarından toplanan örnekler ile Molge luschani olarak tanımlanmış ve 1925 yılında Wolterstorff tarafından Mertensiella cinsine dahil edilmiştir. Yıllar içerisinde türün dağılış alanına yeni lokaliteler eklenerek yeni alttürler teşhis edilmiştir (Göçmen \& Akman, 2012; Göçmen et al., 2013; Üzüm et al., 2015; Y1ldız \& Akman, 2015; Veith et al., 2016). Veith and Steinfartz (2004) mevcut alttürleri morfolojik, alloenzim ve mitokondriyal DNA farklılaşmaları yönünden tekrar incelemiş ve Mertensiella luschani türüne ait olan alttürleri (ssp. basoglui ve ssp. finikensis haricinde), tür seviyesine yükselterek yeni bir cins olarak tanımladıkları Lyciasalamandra altında toplamışlardır. Yapılan son çalışmalarla birlikte, Lyciasalamandra (Veith \& Steinfartz, 2004) cinsi Türkiye' de: L. luschani (Steindachner, 1891), L. atifi (Basoglu, 1967), L. fazilae (Başoğlu \& Atatür, 1974), L. antalyana (Başoğlu \& Baran, 1976), L. billae (Franzen \& Klewen, 1987) ve L. flavimembris (Mutz \& Steinfartz, 1995) olmak üzere ülkemizde altı tür ve Yunanistan'da dağ̣lış gösteren $L$. helverseni (Pieper, 1963) türü ile birlikte dünyada toplam yedi tür içermektedir.

Marmaris semenderi (Lyciasalamandra flavimembris) türü ise ilk olarak Mutz ve Steinfartz tarafından 1995 yılında Mertensiella luschani türünün alt türü olarak tanımlanmıştır (Mutz \& Steinfartz, 1995). Muğla ili sınırları içerisinde dağılış gösteren Marmaris semenderi lokal endemik bir türdür. Ülkemizde yalnızca Güney Batı Anadolu'da Köyceğiz gölünün batı kısmından başlayarak Muğla ili yakın çevresi ile Marmaris ve Ula ilçelerinde dağ1lış gösterir (Franzen et al., 2008; Şenol, 2015; Göçmen \& Karış, 2017; Arslan et al., 2018). Yaşam alanları diğer tüm kara semenderleri gibi yıllık ortalama 800-1500 mm yağış alan yerlerdir (Veith et al., 2001). Sudan tamamen bağımsız yaşayan ve üremek için suya ihtiyaç duymayan bu hayvanlar, ekstrem yaşam koşullarına başarılı bir şekilde uyum gösterirler. Yaşam alanında, sıcak ve kurak zamanlarda kaçabilecekleri nemli ve serin zemin yarıklarına sahip kalkerli kayaçların bulunması gerekmektedir (Baran \& Atatür, 1998). Marmaris semenderleri, gün boyu taş ve kayaların altında veya taş yarıklarında saklanırlar. Bu türü özellikle yağmurlu ya da 
nemli gecelerde toprak veya kaya yüzeyinde görmek mümkündür, hatta sürü halinde toprak yüzeyinde de görülebilmektedir (Veith et al., 2001). Aktif dönemleri dişında yaz uykusu (estivasyon) için daha serin olan toprak altına doğru çekilirler (Steinfartz \& Mutz, 1998).

Marmaris semenderi, IUCN (The International Union for Conservation of Nature = Uluslararası Doğa Koruma Birliği) tarafından "Nesli Tehlike Altında (EN=Endangered) kategorisinde yer verilmiştir. Bunun yanında Bern Sözleşmesinde ise "Koruma Altındaki Fauna Türleri"ni içeren Ek III kategorisinde yer almaktadır. Türün azalmasının ana nedeni olarak orman yangınları nedeniyle habitat kaybı ve bilimsel amaçlar ile aşırı toplanması gösterilmiştir (Kaska et al., 2009).

$\mathrm{Bu}$ çalışma, tür koruma eylem planı çerçevesinde hazırlanmış olup Marmaris semenderinin güncel dağılışının, aktivite döneminin ve bu dönemdeki iklim koşullarının belirlenmesi, türün neslini tehdit eden faktörler ve koruma önerilerinin sunulması amaçlanmıştır.

\section{Materyal ve Metot}

Marmaris semenderinin popülasyon durumu ve türe yönelik tehditlerin araştırılması kapsamında Ekim 2017 Nisan 2019 tarihleri arasında; arazi çalışmaları yapılmıştır. Arazi çalışmaları gündüz saatlerinde uygun habitatlarda taş ve kütük altları kontrol edilerek, geceleri ise fenerle uygun habitatlarda dolaşarak gerçekleştirilmiştir. Birey görülen noktalardan GPS (Garmin Montana 680) ile koordinatları alınmıştır.

Popülasyon yoğunluğu, birim alanda bulunan birey sayısıdır ve çalışılan hayvanın vücut boyutuna veya alanın büyüklüğüne göre birim alan, kilometrekare, hektometrekare veya metrekare olarak seçilir. Amfibilerde ise bu değer genellikle metre veya hektardır (Huang \& Hou, 2004; Measey, 2006). Kara semenderleri ile yapilan çalışmalarda yoğunluk değerleri metrekare ya da hektar olarak verilmiştir (Veith et al., 2001; Papanayotou et al., 1997; Ildırşahin, 2019). Bu nedenle bu çalışmada da yoğunluk hesabı hektar olarak baz alınmıştır. Bu kapsamda her bir lokalitede, 1 hektar olacak şekilde kareleme yöntemi dizayn edilmiş, arazi ve türün tespit edilme durumuna göre kare sayısı arttırılmıştır. Her bir lokalitede en az 3 arazi çalışması yapılmış ve yakalanan en yüksek birey sayısı popülasyon yoğunluğu hesaplamalarında esas alınmıştır.

Çalışma alanına ait meteorolojik veriler, en yakın meteorolojik istasyondan elde edilmiş ve türün yayılış gösterdiği alanın hangi iklim koşullarına sahip olduğu belirlenmiştir. Bu değerler türün dağılış göstermediği Muğla iline ait farklı meteorolojik istasyonlara ait veriler ile de karşılaştırılmıştır. Bu biyoklimatik değişkenler 20002017 yılları arası aylık sıcaklık, yağış ve hava basıncı değerlerinden türetilmiştir Bununla beraber, arazi çalışmaları esnasında, toprak sıcaklığı ve hava sıcaklığı dijital termometre (Digital Pocket Thermometer, $\pm 0.1^{\circ} \mathrm{C}$ ) ile kaydedilmiştir. Elde edilen veriler normal dağılış (Kolmogorov-Smirnov Testi, p>0.05) gösterdiği için bireylerin varlığ ile meteorolojik verilerin karşılaştırılmasında parametrik bir test olan student $t$-test $i$ kullanılmıştır. Saptanan birey sayısı ile meteorolojik veriler arasında ilişki olup olmadığını test etmek için Pearson korelasyon analizi kullanılmıştır.
Marmaris semenderinin bulunduğu lokatilerin koordinatları ArcGIS 10.4 yazılımı kullanarak popülasyon bazlı dağılım haritası oluşturulmuştur. Ayrıca, tespit edilen koordinatlar yükseklik verisi ile eşleştirilerek yüksekliğe bağlı sayısal harita üretilmiştir. ArcGIS ortamında oluşturulan sayısal haritalardan IUCN Kırmızı liste kriterlerinde belirtilen "Dağılış alanı = Extent of occurrance" ve "Yaşam alanı = Area of occupancy" hesaplamaları yapılmıştır.

Arazi çalışmalarındaki biyolojik ve ekolojik gözlemler ile yöre halkı ile ilgili görüşmeler göz önünde bulundurularak, türü tehdit eden faktörler belirlenmeye çalışılmıştır.

\section{Bulgular}

Yapılan arazi çalışmaları ve literatür derlemeleri sonucunda Muğla/Merkez (Kötekli), Ula ve Marmaris ilçelerinde tespit edilen lokaliteler Tablo 1-2 ve Şekil 1'de verilmiştir. Elde edilen bilgiler ışı̆̆ında, türün dağılış gösterdiği en kuzey ve en batı lokaliteler arasında kuşbakışı 72 km'lik bir mesafenin olduğu tespit edilmiştir. Türün yaşam alanının 79 km² ve dağılış alanının 1115 km² olduğu hesaplanmıştır (Şekil 2). Arazi çalışmaları sonucunda türün denizden $843 \mathrm{~m}$ yüksekliğe kadar, literatür çalışmalarına göre ise $890 \mathrm{~m}$ yüksekliğe kadar yaşadığ1 tespit edilmiştir (Tablo 1-2, Şekil 3).

Popülasyon yoğunluğu hakkında yapilan çalışmalarda, popülasyon yoğunluğunun ortalama 5,56 birey/hektar olduğu ve lokalitelerde 1-14 birey/hektar arasında değiştiği tespit edilmiştir (Tablo 2).

Marmaris semenderinin aktif dönemi 2017-2018 dönemi için 29 Ekim 2017 ile 21 Nisan 2018 arasında olduğu (176 gün), 2018-2019 dönemi için ise 1 Kasım 2018 - 24 Nisan 2019 tarihleri (175 gün) arasında olduğu saptanmıştır. Türün aktif olduğu dönemlere ait meteorolojik verilere göre, aylık ortalama sıcaklığın $11.3 \pm 4.31^{\circ} \mathrm{C}\left(\min =5.2^{\circ} \mathrm{C}\right.$; maks $\left.=21^{\circ} \mathrm{C}\right)$, ortalama yağışın $152.6 \pm 74.89 \mathrm{~mm}(\min =56.5 \mathrm{~mm}$; maks $=335.2 \mathrm{~mm})$ ve ortalama hava basincinın $939.6 \pm 2.55 \mathrm{hPa} ;(\min =937.8 \mathrm{hPa}$; maks $=941.4 \mathrm{hPa}$ ) olduğu tespit edilmişltir (Şekil 4-6). Aktif dönemin başlangıcı ilk sonbahar yağmurları ve sicaklıktaki ani düşme $\left(20^{\circ} \mathrm{C}^{\prime}\right.$ nin altında $)$ ile gerçekleşmiştir. Aktif dönem ise sıcaklıkların $24^{\circ} \mathrm{C}$ ve daha üzerinde seyretmesi ile sonlanmıştır. Gözlenen en fazla birey sayısı ise $8-18^{\circ} \mathrm{C}$ arasında (ortalama $=13.72 \pm 1.521^{\circ} \mathrm{C}$ ) gerçekleşmiştir. Bu sıcaklıklar, Aralık ayından Şubat ayı ortalarına denk gelmektedir. Her ne kadar gözlenen birey frekansının hafif yağan yağmurlarda yüksek olmasına rağmen, yağmur miktarı ve hava basıncı ile gözlenen birey sayısı arasında istatistiksel bakımdan önemli bir ilişki saptanamamıştır $(\mathrm{P}>0.05)$.

Marmaris semenderi popülasyonlarını tehdit eden toplam 4 ana faktör tespit edilmiştir. Bunlar, habitat kaybı ya da niteliğinin bozulması, araç trafiği, bireylerin evcil hayvan olarak ve bilimsel amaçlı gereğinden fazla toplanması, evsel ve tarımsal kirleticilerdir.

\section{Tartışma}

Dünyada yalnızca Muğla ili ve ilçelerinde dağılış gösteren Marmaris semenderinin tamamen yok olmasına sebebiyet verebilecek sorunların önlenmesi için mevcut habitatları korumak ve tür izleme çalışmalarını sürdürmek 
gerekmektedir. Bu kapsamda türün yayılış gösterdiği alanların tespit edilmesi ve bu alanlardaki popülasyon yoğunlukları hakkında veriler toplanması ilk yapılacak işlemlerdir. Zira, şu ana kadar yapılan çalışmalar da genellikle taksonomi ve yeni lokalite kayıtlarının tespit edilmesi yönündedir (Başoğlu \& Atatür, 1974; Öz et al., 2004; Şenol, 2015; Üzüm et al., 2015 Göçmen \& Karış, 2017; Arslan et al., 2018). Türün dağılışı ile ilgili yapılan son çalışmada, yeni bulunan lokaliteler ile türün dağılış alanının $45 \mathrm{~km}$ daha güneye uzandığı ve dağılış alanının $115 \mathrm{~km}^{2}$ olduğu belirtilmiştir (Arslan et al., 2018). Arazi ve literatür verilerinin 1şığında, IUCN kırmızı listede coğrafi dağılım kriterleri baz alındığında, Marmaris semenderinin yaşam alanının $79 \mathrm{~km}^{2}$ den daha az olduğu, yayılış alanının ise $1115 \mathrm{~km}^{2}$ den daha az olduğu tespit edilmiştir (Şekil 1). Türün dikey dağılımı ise her ne kadar $600 \mathrm{~m}$ (Kaska et al., 2009) olarak verilmişse de bu çalışmada 843m yükseklikte bireyler tespit edilmiştir. Ancak, Göçmen ve Karış (2017) Sakartepe/Ula mevkisinde tespit ettikleri

popülasyonun denize olan yüksekliğini 890 m olarak vermiştir.

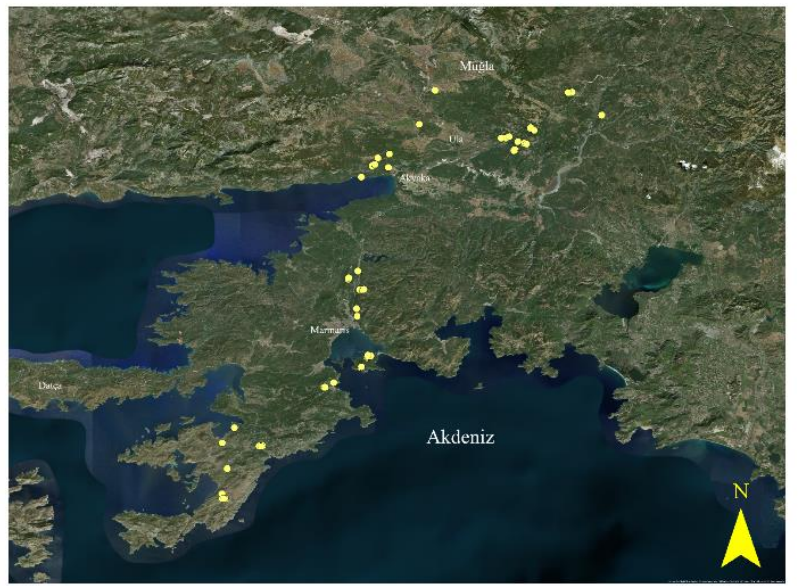

Şekil 1: Arazi çalışmaları ve literatür çalışmaları sonucunda elde edilen Marmaris semenderinin güncel dağılışı

Tablo 1: Literatür derlemesi sonucunda tespit edilen popülasyonlar

\begin{tabular}{|c|c|c|c|c|c|}
\hline Lokalite & Enlem & Boylam & Yükseklik & Birey sayısı & Kaynak \\
\hline Kötekli Mahallesi/Muğla & $37^{\circ} 09^{\prime}$ & $28^{\circ} 22^{\prime}$ & 650 & 8 & Üzüm et al., 2015 \\
\hline Kötekli Mahallesi/Muğla & $37^{\circ} 09^{\prime}$ & $28^{\circ} 23^{\prime}$ & 644 & 8 & \multirow{6}{*}{ Şenol, 2015} \\
\hline Bahçeli-Bayır arası Bayır'a 2 km /Marmaris/Muğla & $36^{\circ} 41^{\prime}$ & $28^{\circ} 09^{\prime}$ & 312 & 12 & \\
\hline Turunç, Marmaris/Muğla & $36^{\circ} 46^{\prime}$ & $28^{\circ} 14^{\prime}$ & 191 & 6 & \\
\hline Çiçekli Köyü-Ula/Muğla & $37^{\circ} 05^{\prime}$ & $28^{\circ} 30^{\prime}$ & 683 & 7 & \\
\hline Yaylasöğüt Köyü/Muğla & $37^{\circ} 09^{\prime}$ & $28^{\circ} 33^{\prime}$ & 822 & 9 & \\
\hline Taşlıca-Serçe Limanı Yolu 2. km Marmaris/Muğla & $36^{\circ} 37^{\prime}$ & $28^{\circ} 05^{\prime}$ & 167 & 25 & \\
\hline Kötekli Mahallesi/Muğla & $37^{\circ} 09^{\prime}$ & $28^{\circ} 22^{\prime}$ & 660 & 6 & \multirow{10}{*}{ Göçmen \& Karış, 2017} \\
\hline Thera Antik Kenti/Ula/Muğla & $37^{\circ} 07^{\prime}$ & $28^{\circ} 21^{\prime}$ & 700 & 10 & \\
\hline Akyaka/Ula/Muğla & $37^{\circ} 03^{\prime}$ & $28^{\circ} 17^{\prime}$ & 390 & 10 & \\
\hline İncir Mevki/Armutçuk/Ula/Muğla & $37^{\circ} 06^{\prime}$ & $28^{\circ} 28^{\prime}$ & 600 & 1 & \\
\hline Çiçekli Köyü/Ula/Muğla & $37^{\circ} 05^{\prime}$ & $28^{\circ} 29^{\prime}$ & 615 & 7 & \\
\hline Marmaris 6. Km/Muğla & $36^{\circ} 55^{\prime}$ & $28^{\circ} 16^{\prime}$ & 90 & 2 & \\
\hline Marmaris $6 . \mathrm{km} / \mathrm{Muğla}$ & $36^{\circ} 55^{\prime}$ & $28^{\circ} 16^{\prime}$ & 90 & 5 & \\
\hline Cennet Adası/Marmaris/Muğla & $36^{\circ} 48^{\prime}$ & $28^{\circ} 17^{\prime}$ & 100 & 11 & \\
\hline Sakartepe/Kızılağaç/Ula/Muğla & $37^{\circ} 04^{\prime}$ & $28^{\circ} 19^{\prime}$ & 890 & 1 & \\
\hline Kuyucak/Ula/Muğla & $37^{\circ} 04^{\prime}$ & $28^{\circ} 18^{\prime}$ & 750 & 2 & \\
\hline Arıcılar /Ula/Muğla & $36^{\circ} 6^{\prime}$ & $28^{\circ} 35^{\prime}$ & 650 & 6 & \multirow{7}{*}{ Arslan et al., 2018} \\
\hline Turunç, Marmaris/Muğla & $36^{\circ} 47^{\prime}$ & $28^{\circ} 12^{\prime}$ & 30 & 14 & \\
\hline Turgut Şelalesi/Selimiye/Marmaris/Muğla & $36^{\circ} 43^{\prime}$ & $28^{\circ} 7^{\prime}$ & 10 & 4 & \\
\hline Selimiye, Marmaris/Muğla & $36^{\circ} 41^{\prime}$ & $28^{\circ} 6^{\prime}$ & 60 & 10 & \\
\hline Söğütköy, Marmaris/Muğla & $36^{\circ} 40^{\prime}$ & $28^{\circ} 6^{\prime}$ & 150 & 5 & \\
\hline Taşlıca, Marmaris/Muğla & $36^{\circ} 38^{\prime}$ & $28^{\circ} 6^{\prime}$ & 240 & 2 & \\
\hline Taşlıca, Marmaris/Muğla & $36^{\circ} 37^{\prime}$ & $28^{\circ} 6^{\prime}$ & 240 & 2 & \\
\hline
\end{tabular}

Tablo 2: Arazi çalışmaları sonucunda tespit edilen popülasyonlar ve Mutlak Popülasyon Yoğunlukları

\begin{tabular}{lcccc}
\hline Popülasyon adı & Enlem & Boylam & Yükseklik & Birey sayısı \\
\hline Yaylasöğ̈ü/Muğla & $37^{\circ} 09^{\prime}$ & $28^{\circ} 33^{\prime}$ & 843 & 5 \\
(Birey/Hektar)
\end{tabular}

Yapılan arazi çalışmaları sonucunda elde edilen diğer bir önemli konuda türün yılın hemen hemen yarısını aktif olarak geçirdiğidir. Ekim ayı sonu Kasım ayı başlarında gözlenmeye başlayan bireyler Nisan ayı sonlarına kadar aktif olarak rastlanabilmektedir. Marmaris semenderine komşu olan bir diğer kara semenderi türü olan L. fazilae' ninde aktif dönemleri hemen hemen aynı tarihlere rast gelmektedir (Polat \& Başkale,
2018). Gözlenen en fazla birey sayısı ise Aralık ayından Şubat ayı ortalarına kadar hava sıcaklığın $8-18^{\circ} \mathrm{C}$ arasında olduğu dönemlere denk gelmektedir. Her ne kadar hava sıcaklığının $3^{\circ} \mathrm{C}$ olduğu dönemde birey gözlense de daha düşük sıcaklıklarda herhangi bir bireye rastlanmamıştır. Benzer şekilde L. fazilae' nin aktif döneminin $22^{\circ} \mathrm{C}$ ve daha yüksek sıcaklıklarda sonlandığ 1 ve en fazla bireyin $2-18^{\circ} \mathrm{C}$ aralığında gözlendiği belirtilmiştir (Polat \& Başkale, 2018). 
Diğer yandan Rödder et al. (2011) 19 biyoklimatik veri seti kullanarak Likya semenderi türleri arasındaki klimatik niş benzerliklerini araştırmışlardır. Bu çalışmada L. helverseni hariç diğer Likya semenderi türlerinin benzer klimatik koşullara sahip olduğu, yılın en soğuk çeyreğinde ortalama sıcaklıkların $6-12.5^{\circ} \mathrm{C}$ (BIO 11) arasında değiştiği ortalama yağış miktarının 350-620 mm (BIO 19) olduğunu belirtmişlerdir. Bu çalışmada, türün dağılış gösterdiği Marmaris, Ula ve Muğla Merkez Meteoroloji istasyonlarından elde edilen veriler, türün aktif dönemlerindeki aylık ortalama sıcaklıkların $5-21^{\circ} \mathrm{C}$ ), aylık ortalama yağışın 57-335 $\mathrm{mm}$ ve aylık ortalama hava basıncının 938-941 $\mathrm{hPa}$ arasında gerçekleştiğini göstermiştir. Ancak, yağmur miktarı ve hava basıncı ile gözlenen birey sayısı arasında herhangi bir ilişki saptanamamasına rağmen, en fazla birey yavaş yağan yağmurlu günlerde özellikle hava karardıktan sonra gözlenmiştir.

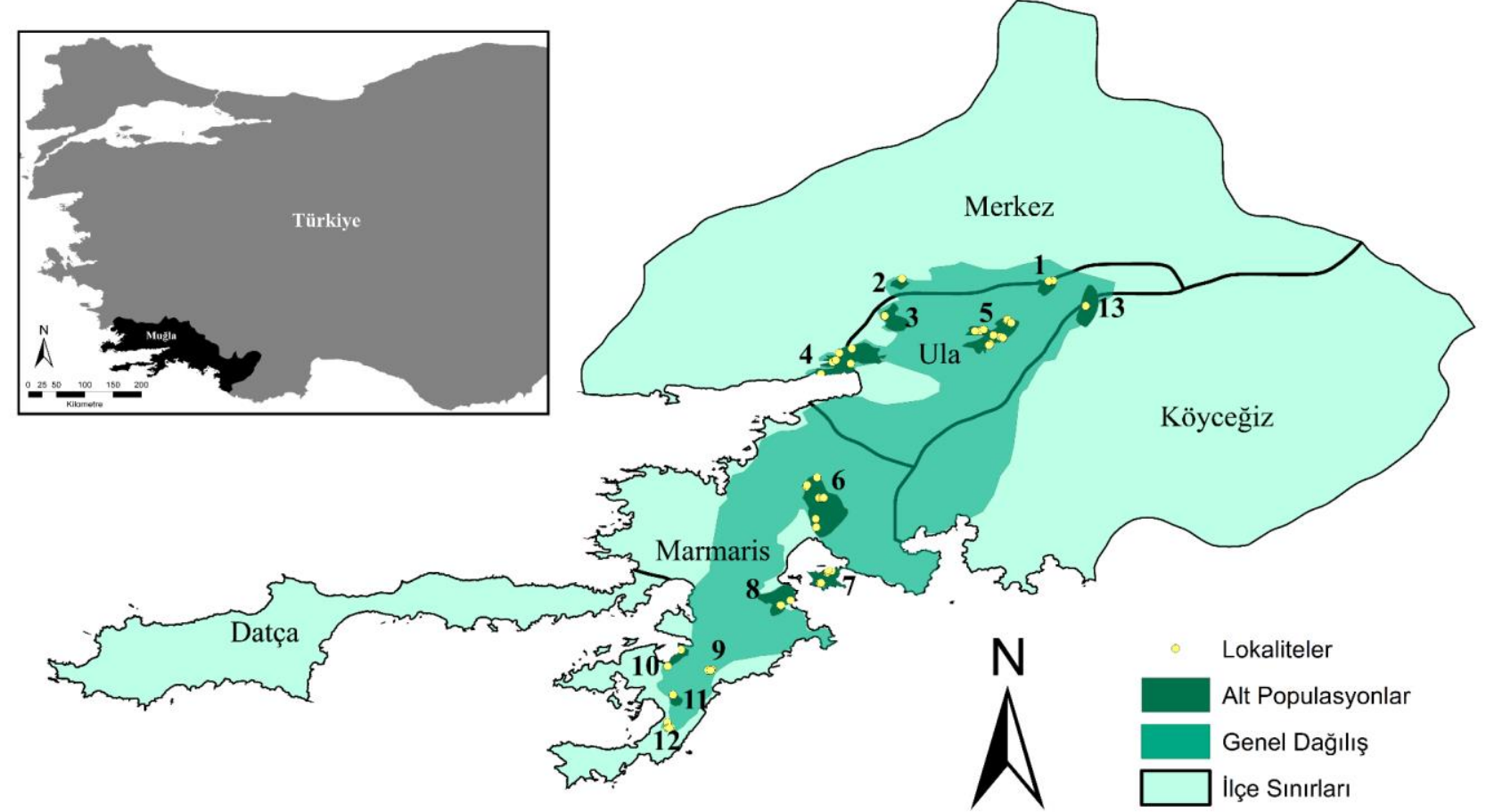

Şekil 2: Marmaris semenderinin popülasyon bazlı güncel dağılımı (1:Yaylasöğüt, 2:Kötekli, 3:Thera Antik Kenti, 4:Akyaka, 5:ÇiçekliArmutçuk, 6:Marmaris, 7:Cennet adası, 8:Turunç, 9:Bayır, 10:Selimiye, 11:Söğütköy, 12:Taşlıca, 13: Arıcılar)

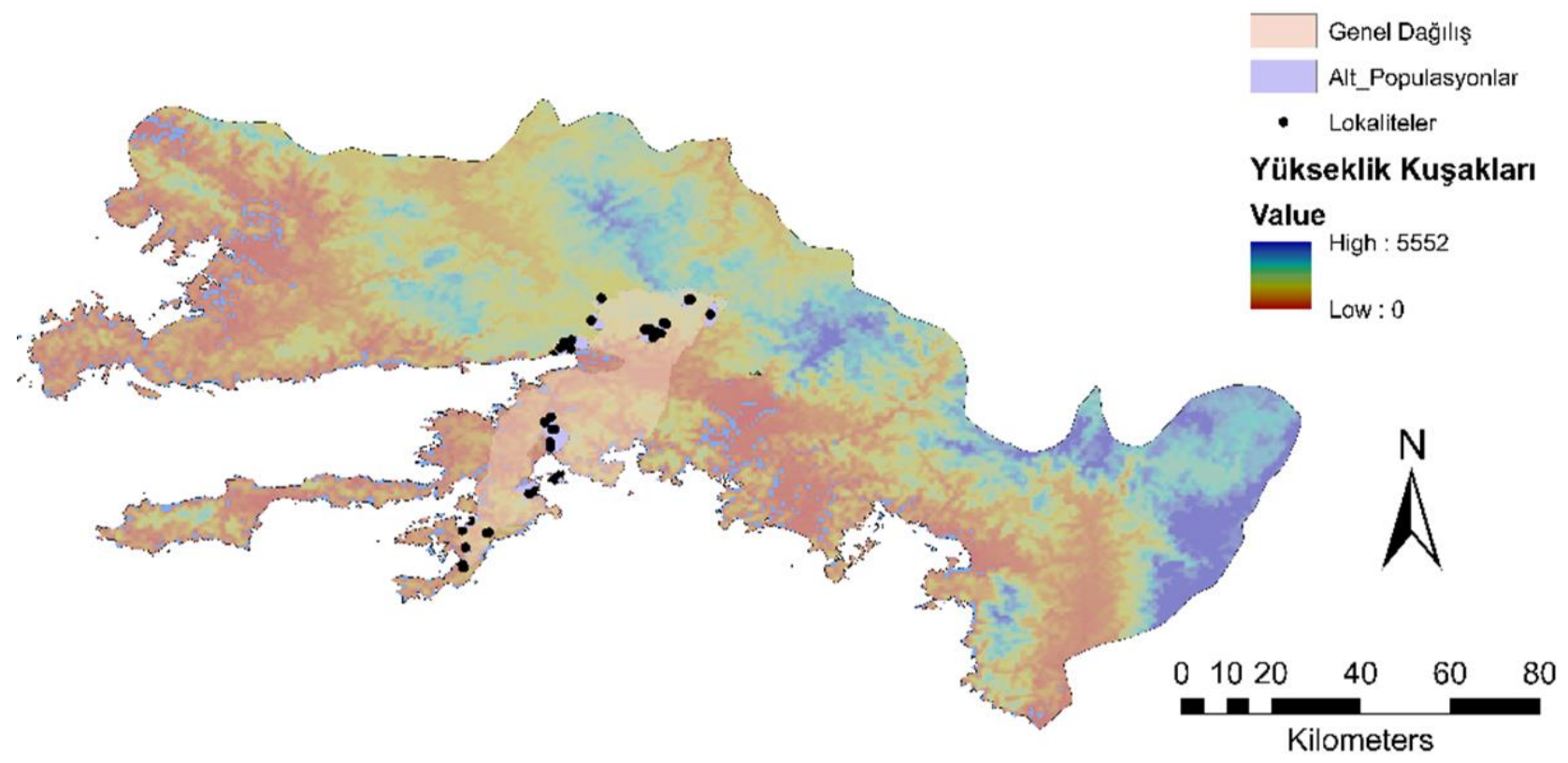

Şekil 3: Marmaris semenderinin güncel dağılışına ait yükseklik kuşakları

Popülasyon yoğunluğu hesaplamaları göz önüne alındığında, birey yoğunluğunun en düşük olduğu alan Taşlıca mevkisi iken en yoğun olduğu lokaliteler ise
Cennet Adası ve Marmaris popülasyonları olduğu belirlenmiştir. Bu iki bölge de Marmaris Doğa Koruma Milli Parklar sınırları içerisinde olup, türün en iyi 
korunduğu alanlardır. Benzer şekilde Cennet adasında 2016 yılında yapılan bir çalışmada Marmaris semenderinin popülasyon yoğunluğu 4.74- 12.63 birey/hektar olarak hesaplanmıştır (Dereağzı, 2016). Marmaris semenderinin popülasyon yoğunluğu ile ilgili tek bir çalışma mevcuttur. Lyciasalamandra cinsine ait bazı akraba türlerin popülasyon yoğunluğuna ait çalışmalar ise sınırlı sayıdadır. Örneğin Lyciasalamandra helverseni' nin Meis (=Kastellerizo) adası popülasyon yoğunluğunu, Papanayotou et al. (1997) 5000 birey/hektar olarak hesaplarken, Veith et al. (2001) ayn popülasyonun yoğunluğunu 10000 birey/hektar olarak vermiştir. Olgun (2013) ise Tersane adasındaki Lyciasalamandra fazilae'nin popülasyon yoğunluğu 21-44 birey/hektar olarak hesaplanmıştır. Bu konudaki son çalışma ise Ildırşahin (2019) tarafından yapılmış olup Lyciasalamandra atifi'nin Türbelinaz'daki popülasyon yoğunluğu 8 birey/hektar olarak hesaplanmıştır.

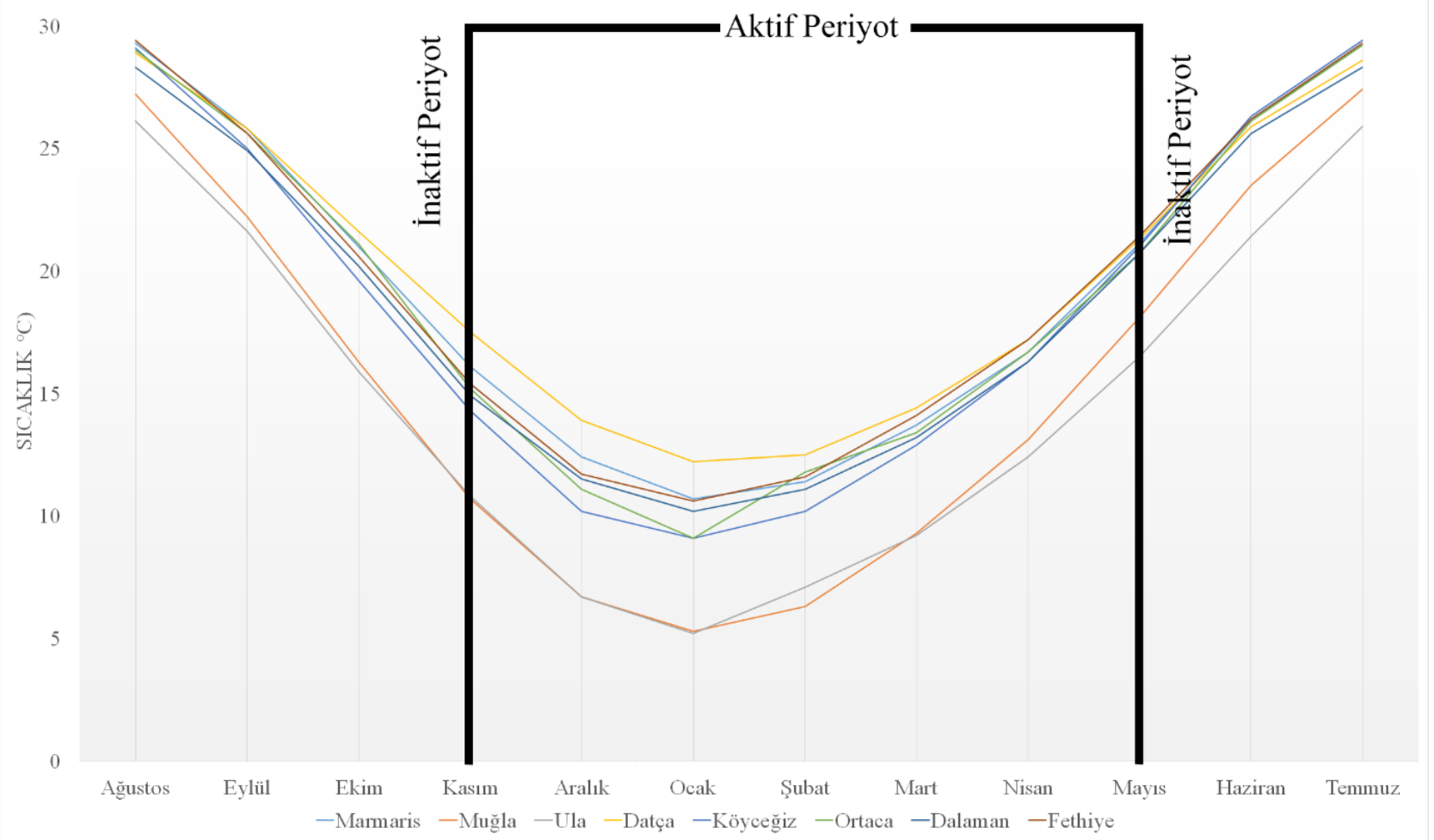

Şekil 4: Farklı meteorolojik istasyonların ölçümlerine göre Muğla ili aylık sıcaklık ortalamaları

300

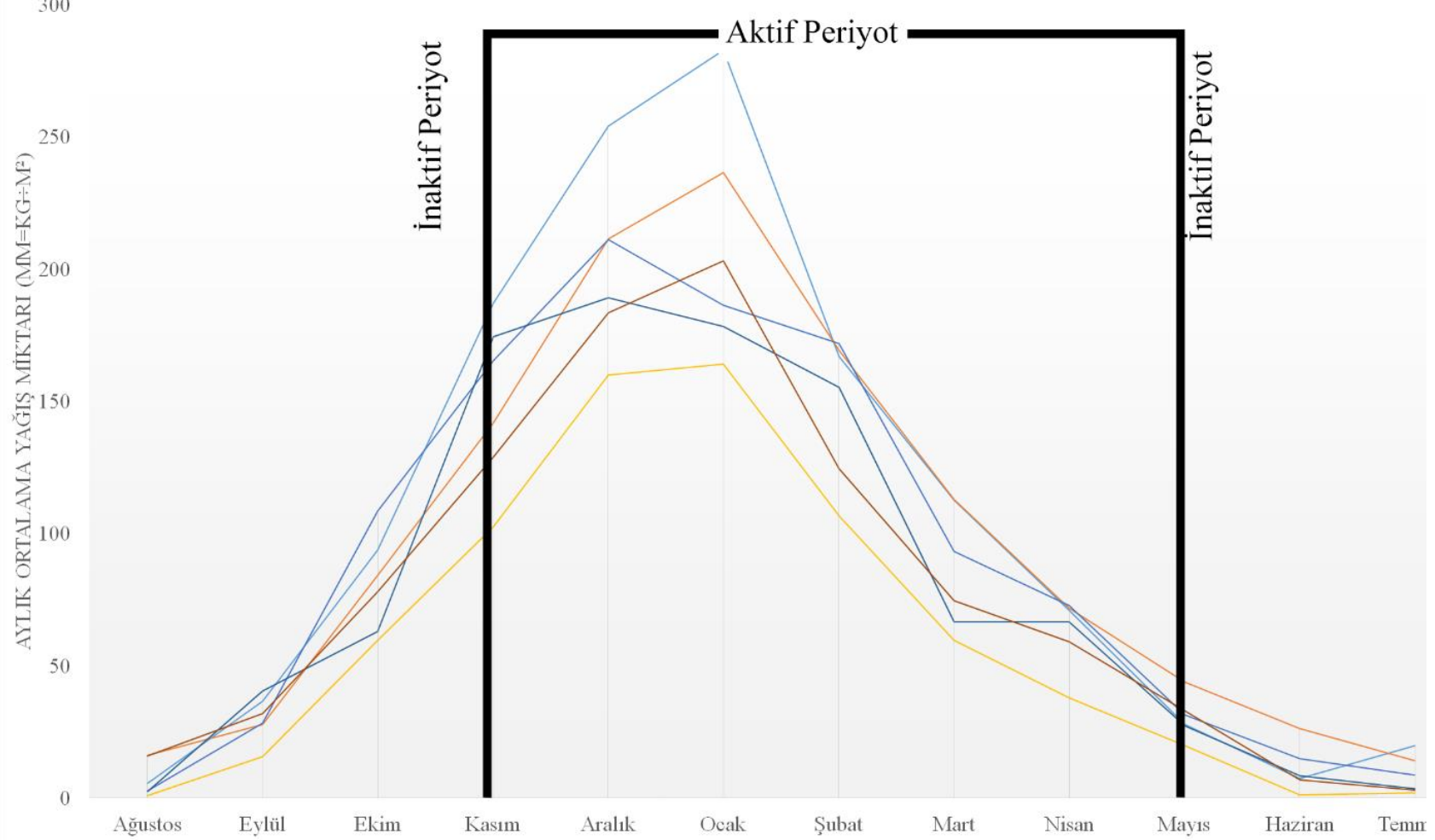

Şekil 5: Farklı meteorolojik istasyonların ölçümlerine göre Muğla ili aylık yağış miktarı ortalamaları 


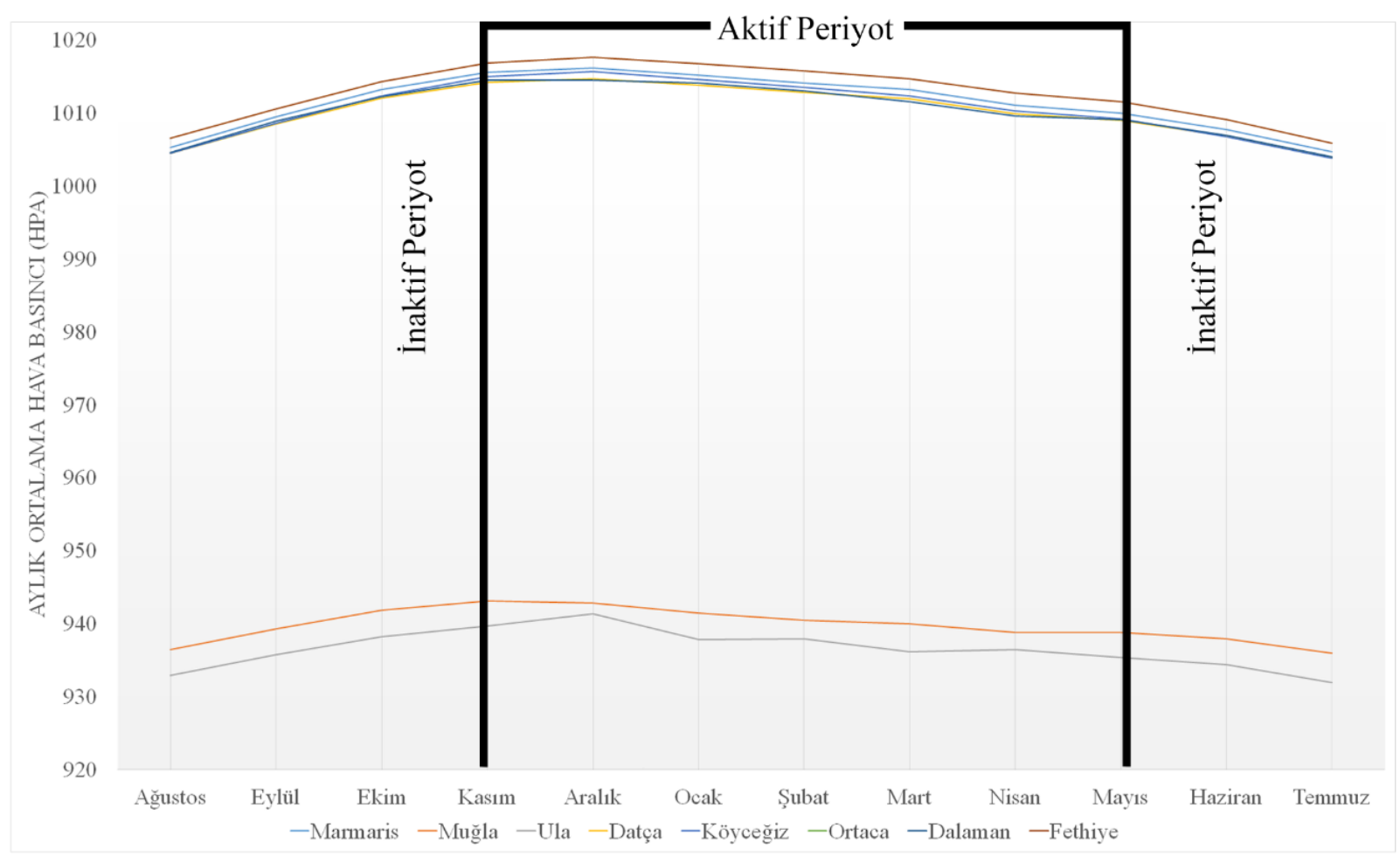

Şekil 6: Farklı meteorolojik istasyonların ölçümlerine göre Muğla ili aylık hava basıncı ortalamaları

Marmaris semenderi popülasyonlarını tehdit eden faktörler incelendiğinde, habitat kaybı ya da niteliğinin bozulması başlı̆̆ı altında, yoğun bir şekilde yapılaşma, tarım faaliyetleri, yol yapım çalışmaları, orman yangınları, ormancılık faaliyetleri gelmektedir. Bölgenin önemli bir turizm alanı olması beraberinde otel, yazlık ev vb. binaların artışına ve yeni yollar inşa edilmesine neden olmaktadır. Aynı zamanda, yöre halkının tarım alanlarını yeniden yapılandırarak, geleneksel tarımdan endüstriyel tarıma geçiş faaliyetleri, bazı ormanlık alanların tarım arazisine dönüştürülmesi, evsel atıklar ve moloz yığınlarının habitatlara dökülmesi türün yaşam alanlarının niteliğinin bozulmasına ya da yok olmasına neden olmaktadır. Ayrıca yapılan çalışmalar esnasında, tarımsal ilaçlamaların yapıldığı ve çok sayıda tarımsal ilaç şişesi türün habitatlarına atıldığı gözlemlenmiştir. Tarımsal ilaçların direkt olarak Marmaris semenderine nasıl etki ettiği bilinmemektedir. Ancak, besin diyetindeki canlıları öldürdüğü için besin çeşitliliğinin azalması ya da pestisitler tarafından etkilenmiş canlıları tüketerek indirekt yoldan etkilendiği düşünülebilir. Diğer yandan ormanlık alanlarda bilinçsizce yapılan ağaç kesimleri, tomrukların istiflenmesi ve taşınması habitat bozulmalarına ya da birey ölümlerine neden olurken, çıkabilecek orman yangınları türün habitatlarını tamamen yok edebilecektir. Diğer önemli bir konu ise yağışl1 havalarda bireylerin yollara çıkması ve araçlar tarafından ezilmesidir. Özellikle Marmaris yolu (6.km), Çiçekli, Armutçuk, Akyaka ve Turunç popülasyonları yoğun risk altındadır. Marmaris semenderinin neslini tehdit eden bir diğer konu ise bireylerin evcil hayvan olarak ve bilimsel amaçlı gereğinden fazla toplanmasıdır. Özellikle yöre halkı ile yapılan görüşmelerde yerli ve yabancı turistler ile bilim insanlarının bilinçli bir şekilde bireyleri herhangi bir yasal izin almadan yakalayarak besleme amaçli alıkoydukları bildirilmiştir. Özellikle, popülasyon yoğunluğunun düşük olduğu lokalitelerde toplanan her bir birey popülasyonun geleceğini tehdit etmektedir. Yukarıda bahsedilen faktörler arazi çalışmaları esnasında gözlemlediğimiz öngörülerdir. $\mathrm{Bu}$ faktörlerin popülasyonlara nasıl etki ettiği uzun vadeli izleme çalışmaları ile desteklenmesine ihtiyaç vardır.

Teşekkür: Bu çalışma, T.C. Orman ve Su İşleri Bakanlığı, Doğa Koruma ve Milli Parklar Genel Müdürlüğü, IV. Bölge Müdürlüğü, Muğla Şube Müdürlüğü tarafından yürütülen “'Muğla İli Marmaris Semenderi (Lyciasalamandra flavimembris) Tür Eylem Planı" projesi kapsamında hazırlanmıştır. Projenin aşamalarında desteklerini esirgemeyen DKMP IV. Bölge Müdürü Sayın Kerim GENÇOĞLU'na, Bölge Müdür Yardımcıları Sayın Osman MALKOÇ ve Mehmet İbrahim ÇOLAK'a, Sulak Alanlar Şube Müdürü Mehmet UZUNER'e, Avcilık ve Yaban Hayatı Şube Müdürü Hasan PAŞALI'ya teşekkür ederiz. Ayrıca proje boyunca her konuda yardımlarını esirgemeyen, Datça DKMP Şefi V. Uğurcan ÖZTOKAT'a teşekkür ederiz.

\section{Kaynaklar}

Arslan, D., Yaşar, Ç., İzgin, A., Şen, C., \& Çiçek, K. (2018). New sites of the endangered Marmaris Salamander, Lyciasalamandra flavimembris (Mutz and Steinfartz 1995), (Caudata: Salamandridae) from Muğla, Turkey. Amphibian \& Reptile Conservation, 12(2), 106-111.

Baran, I., \& Atatür, M. (1998). The Herpetofauna of Turkey (amphibians and reptiles). Republic of Turkey, Ministry of the Environment, Ankara, Türkiye, $214 \mathrm{pp}$.

Başoğlu, M., \& Atatür, M. (1974). The subspecific division of the Lycian salamander, Mertensiella luschani (Steindachner) in Southwestern Anatolia. İstanbul Üniversitesi Fen Fakültesi Mecmuası Seri B, 39(3-4), 147155.

Dereağzı, E. (2016). Cennet Adası (Marmaris)'nda Yaşayan Lyciasalamandra flavimembris Türünün Populasyon Yoğunluğunun Saptanması (Yüksek Lisans Tezi). Ege Üniversitesi, İzmir, Türkiye.

Franzen, M., Bußmann, M. \& Kordges, T. \& Thiesmeier, B. (2008). Die amphibien und reptilien der Südwest-Türkei: Bielefeld, Germany Laurenti-Verlag, 328 pp. 
Göçmen, B., \& Akman, B. (2012). Lyciasalamandra arikani n. sp. \& L. yehudahi n. sp. (Amphibia: Salamandridae), two new Lycian salamanders from Southwestern Anatolia. North-Western Journal of Zoology, 8, 181-194.

Göçmen, B., \& Karış, M. (2017). Comparative study on the endangered Marmaris Lycian salamander populations, Lyciasalamandra flavimembris (Mutz \& Steinfartz, 1995) (Caudata: Salamandridae), with the description of several new localities. North-Western Journal of Zoology, 13(1), 49-57.

Göçmen, B., Veith, M., Akman, B., Godmann, O., İğci, N., \& Oğuz, M. A. (2013). New records of the Turkish Lycian salamanders (Lyciasalamandra, Salamandridae). North-Western Journal of Zoology, 9(2), 319-328.

Huang, C.-Y., \& Hou, P.-C. L. (2004). Density and diversity of litter amphibians in a monsoon forest of southern Taiwan. Zoological Studies, 43(4), 795-802.

Ildırşahin, H. (2019). Türbelünaz'da (Alanya/Antalya) yaşayan Lyciasalamandra atifi (Başoğlu, 1967) (Urodela: Amphibia)'nin populasyon yoğunluğunun hesaplanması (Yüksek Lisans Tezi), Ege Üniversites, İzmir, Türkiye.

Kaska, Y., Kumlutaş, Y., Avcl, A., Üzüm, N., Yeniyurt, C., Akarsu, F., Tok, V., Uğurtaş, I.H., Sevinç, M., Crochet, P.A., Papenfuss, T., Sparreboom, M., Kuzmin, S., Anderson, S., \& Denoël, M. (2009). Lyciasalamandra flavimembris. The IUCN RedList of Threatened Species 2009: $\begin{array}{lll}\text { e.T61917A12572380. } & \text { Retrieved } & \text { from }\end{array}$ https://www.iucnredlist.org/species/61917/12572380

Measey, G. (2006). Surveying biodiversity of soil herpetofauna: towards a standard quantitative methodology. European Journal of Soil Biology, 42, 103-110.

Mutz, T., \& Steinfartz, S. (1995). Mertensiella luschani flavimembris ssp. n., eine neue Unterart des Lykischen Salamanders aus der Türkei (Caudata: Salamandridae). Salamandra, 31, 137-148.

Olgun, M. (2013). Tersane Adasında (Göcek/Muğla) Yaşayan Lyciasalamandra fazilae (Başoğlu-Atatür 1974) (Urodela: Amphibia)'nin Populasyon Yoğunluğunun Hesaplanması (Yüksek Lisans Tezi), Ege Üniversitesi, İzmir, Türkiye.

Öz, M., Düşen, S., Tunç, M.R., Kumlutaş, Y., Durmuş, H., \& Kaska, Y. (2004). A morphological and taxonomical study on the subspecies of the Lycian salamander, Mertensiella luschani, (Steindachner, 1891) (Urodela: Salamandridae). Turkish Journal of Zoology, 28(3), 237-244.

Papanayotou, K., Radea, K., \& Polymeni, R.M. (1997). Food habits and trophic availability of an insular population of Mertensiella luschani (Urodela) on the island of Kastellorizo (S.E. Aegean, Greece). The 3rd World Congress in Herpetology, Prague.

Polat, F., \& Başkale, E. (2018). Phenology and factors influencing the abundance of Lyciasalamandra fazilae (Amphibia: Salamandridae) in Turkey. Salamandra, 54, 123-131.

Rödder, D., Lötters, S., Öz, M., Bogaerts, S., Eleftherakos, K., \& Veith, M. (2011). A novel method to calculate climatic niche similarity among species with restricted ranges-the case of terrestrial Lycian salamanders. Organisms Diversity \& Evolution, 11, 409-423.

Steinfartz, S. \& Mutz, T. (1998). Mertensiella luschani (Steindachner, 1891)Lykischer Salamander, Kleinasiatischer Salamander, In K. Grossenbacher, B. Thiesmeier (Ed.), Handbuch der Reptilien und Amphibien Europas, vol. 4/1, Schwanzlurche. Aula: Wiesbaden, pp. 367-397.

Şenol, A. (2015). Lyciasalamandra flavimembris (Mutz and Steinfartz, 1995)'in (Amphibia: Urodela) taksonomik durumu (Yüksek Lisans Tezi). Adnan Menderes Üniversitesi, Aydın, Türkiye.

Üzüm, N., Avc1, A., Bozkurt, E., \& Olgun, K. (2015). A new subspecies of Lyciasalamandra flavimembris (Urodela: Salamandridae) from Muğla, southwestern Turkey. Turkish Journal of Zoology, 39(2), 238-334.

Veith, M., \& Steinfartz, S. (2004). When non-monophyly results in taxonomic consequences-the case of Mertensiella within the Salamandridae (Amphibia: Urodela). Salamandra, 40(1), 67-80.

Veith, M., Baran, İ., Godmann, O., Kiefer, A., Öz, M., \& Tunç, M.R. (2001). A revision of population designation and geographic distribution of the Lycian salamander Mertensiella luschani (Steindachner, 1891). Zoology in the Middle East, 22(1), 67-82.

Veith, M., Göçmen, B., Sotiropoulos, K., Kieren, S., Godmann, O., \& Steinfartz, S. (2016). Seven at one blow: the origin of major lineages of the viviparous Lycian salamanders (Lyciasalamandra Veith and Steinfartz, 2004) was triggered by a single paleo-historic event. Amphibia-Reptilia, 37, 373-387.

Yıldız, M.Z., \& Akman, B. (2015). A New Subspecies of Atif's Lycian Salamander Lyciasalamandra atifi (Başoglu, 1967), from Alanya (Antalya, Turkey). Herpetozoa, 28(1-2), 3-13. 